\title{
Role of Dopamine DI Receptors in the Activation of Nucleus Accumbens Extracellular Signal-Regulated Kinase (ERK) by Cocaine-Paired Contextual Cues
}

\author{
Ashley N Fricks-Gleason' and John F Marshall ${ }^{*, 1}$ \\ 'Department of Neurobiology and Behavior, University of California, Irvine, CA, USA
}

\begin{abstract}
Exposure to drug-paired cues can trigger addicts to relapse into drug seeking. Although the molecular mechanisms underlying cue-elicited cocaine seeking are incompletely understood, the protein kinase extracellular signal-regulated kinase (ERK) is known to have an important role. Psychostimulants and their associated cues can activate ERK in medium spiny neurons of the nucleus accumbens core $(A c b C)$. These medium spiny neurons can be classified according to their projections (to ventral pallidum and/or substantia nigra) and by their mRNA expression. The present experiments were designed to determine which distinct set of AcbC projection neurons expresses phosphorylated ERK ( $p E R K$ ) in response to cocaine-paired contextual cues. Combined use of the retrograde label Flurogold with immunohistochemical staining of pERK was used to show that the AcbC pERK accompanying preference for cocaine-paired contexts occurs in both the accumbens (Acb)-nigral and Acb-pallidal projections. The gene expression characteristics of the neurons expressing pERK in response to cocaine-paired cues was further investigated using combined in situ hybridization and immunocytochemistry to show that AcbC pERK + cells correspond to DI, but not preproenkephalin, mRNA + cells. Furthermore, intra-AcbC infusion of the DIantagonist SCH23390 attenuated cue-induced AcbC pERK expression. In aggregate, these results indicate that (i) the DI-expressing AcbC neurons evidence long-term plasticity related to drug-cue memories and (ii) local dopamine DI receptors are necessary for the expression of cocaine-paired cue-induced pERK in these AcbC neurons.

Neuropsychopharmacology (20II) 36, 434-444; doi:I0.1038/npp.2010.174; published online 13 October 2010
\end{abstract}

Keywords: MAP kinase; conditioned place preference; addiction; craving; relapse; rat

\section{INTRODUCTION}

The relapse of addicts into drug seeking is often triggered by discrete cues or contexts paired with drug exposure. Neutral cues previously paired with drug use take on incentive motivational properties that can lead to an intense craving by addicts (Childress et al, 1988). The molecular mechanisms underlying drug-cue associations are a topic of active investigation (Chao and Nestler, 2004; Kalivas, 2004; Hyman et al, 2006). Among the molecules under consideration, the protein kinase extracellular signal-regulated kinase (ERK) is known to have a crucial role. Psychostimulants and drugpaired cues both activate the ERK signaling cascade inducing phosphorylation of ERK in the nucleus accumbens (Acb) (Berhow et al, 1996; Valjent et al, 2000; Miller and Marshall, 2005b). Importantly, unlike psychostimulants, which activate ERK in both the nucleus Acb core (AcbC) and shell (Valjent

*Correspondence: Dr JF Marshall, Department of Neurobiology and Behavior, University of California, 2205 McGaugh Hall, Irvine, CA 92670-4550, USA, Tel: + I 949824 6636, Fax: + I 9498242447 ,

E-mail: jfmarsha@uci.edu

Received I April 20I0; revised 30 August 2010; accepted 30 August 2010 et al, 2000), drug-paired cues have been shown to activate ERK solely in the AcbC (Miller and Marshall, 2005b).

The AcbC is of particular interest in cue-induced craving because of its position as an output nucleus of the basal ganglia (Heimer et al, 1991; Groenewegen et al, 1999) and its role in the control of the affective and motivational aspects of behavior (Le Moal and Simon, 1991; Mogenson and Yang, 1991). Dopaminergic neurons located in the ventral tegmental area provide synaptic input to the AcbC (Beckstead et al, 1979; Smith and Bolam, 1990) and modulate output by activation of D1- and D2-class dopamine (DA) receptors (White and Wang, 1986). As in the caudate-putamen, AcbC cells expressing D1 receptors co-express dynorphin, whereas cells expressing D2 receptors co-express enkephalin (Curran and Watson, 1995). Furthermore, these D1- and D2-class receptors are principally expressed in separate neuron populations of the AcbC (Le Moine and Bloch, 1995).

DA release during drug use has a critical role in the addiction circuitry. The firing of midbrain DA cells serves as a reward signal during appetitive learning (Schultz et al, 1997), and DA receptors in the AcbC are necessary for the acquisition (Liao, 2008) and expression (Hiroi and White, 1991) of psychostimulant conditioned place preference 
(CPP). AcbC DA receptors are upstream mediators of cocaine-induced phosphorylation of ERK (Valjent et al, 2005). Furthermore, this cocaine-induced phosphorylation of ERK occurs specifically in the D1-containing subpopulation of AcbC neurons (Valjent et al, 2005). Although phosphorylated ERK (pERK) in the AcbC is strongly implicated in the storage and retrieval of drug-cue memories; little research has attempted to elucidate which specific population of AcbC neurons is involved in cueelicited drug seeking. As in the caudate-putamen (Kemp and Powell, 1971) as much as $95 \%$ of the AcbC is comprised of spiny projection neurons (Chang and Kitai, 1985), with the remainder being acetylcholinergic or GABAergic interneurons (Bolam et al, 1984; Kita, 1993). These spiny projection neurons send both D1/dynorphin- and D2/ enkephalin-expressing efferents to the ventral pallidum (VP), whereas only D1/dynorphin-expressing cells project to the ventral tegmental area and substantia nigra (SN) (Heimer et al, 1991; Lu et al, 1997; Lu et al, 1998). Identifying which of these specific AcbC neuron populations exhibits pERK during expression of drug-cue memories is a critical first step in determining how ERK-dependent plasticity is induced. The results presented here provide information that could be used to develop molecular approaches targeting these neurons displaying pERK over-expression related to addiction.

\section{MATERIALS AND METHODS}

\section{Animals}

Male Sprague-Dawley rats were individually housed on a 12-h light/dark cycle with ad libitum access to food and water. The housing conditions and care of the animals were in accordance with those specified in the Guide for the Care and Use of Laboratory Animals (Institute of Animal Resources, Commission on Life Sciences, National Research Council, 1996). All procedures were performed during the light part of the diurnal cycle. Rats to undergo surgery weighed 275-300 $g$ and were handled for 2 days before surgery and allowed 3 days of recovery before behavioral conditioning.

\section{Place Preference Apparatus and Control Environment}

Conditioning took place in a three-chamber CPP apparatus (Med Associates, St Albans, VT) consisting of two larger compartments $(28 \times 21 \mathrm{~cm})$ separated by a smaller compartment $(12 \times 21 \mathrm{~cm})$. The two larger compartments were distinguished by different visual, olfactory, and tactile cues (Fricks-Gleason and Marshall, 2008). In addition to training in the CPP apparatus, animals were placed in an alternate environment for control purposes (Miller and Marshall, $2005 \mathrm{~b})$. The control environment consisted of a clear plastic cage $(27 \times 48 \mathrm{~cm})$, distinct from the home cage, located in a room independent of both the CPP apparatus and the holding room.

\section{Behavioral Procedures}

For the retrograde labeling and gene expression studies, CPP training and testing was conducted as described previously (Miller and Marshall, 2005b), using cocaine-HCl (12 mg/kg) or saline $(1 \mathrm{ml} / \mathrm{kg}$, i.p.; Figure 1$)$. For studies involving intraAcbC SCH23390 infusion, animals were assessed for baseline preference, and then divided into two drug-paired groups (to be given SCH23390 or vehicle) having equal initial preferences for each compartment. Conditioning took place over the next 9 days. At $48 \mathrm{~h}$ post-conditioning, animals received a bilateral intra-AcbC infusion of SCH23390 $(0.5 \mu \mathrm{g}$ in $0.5 \mu \mathrm{l}$ saline) or vehicle $(0.5 \mu$ l over $2 \mathrm{~min}$; through a 33 ga infuser projecting $1.5 \mathrm{~mm}$ beyond the tip of the guide cannula) immediately before $15 \mathrm{~min}$ confinement to the previously cocaine-paired compartment.

\section{Retrograde Labeling of AcbC Neurons Projecting to the Substantia Nigra or Ventral Pallidum}

Fluorogold (FG) iontophoresis was performed as described previously (Miller and Marshall, 2005a) into either the SN (AP: $-5.3 \mathrm{~mm}$ relative to bregma, ML: $\pm 1.8 \mathrm{~mm}$, and DV: $-8.9 \mathrm{~mm}$ from skull) or VP (alkaline phosphatase (AP): $0 \mathrm{~mm}$, ML: $\pm 2.3 \mathrm{~mm}$, and DV: $-8.3 \mathrm{~mm}$ from skull) (Paxinos and Watson, 2005) of opposite hemispheres. Because the AcbC projections do not cross hemispheres (Robertson and Jian, 1995), FG was iontophoresed into different structures in each hemisphere for subsequent analysis of retrograde labeling in each of the corresponding AcbC.

\section{Implantation of Bilateral AcbC Guide Cannulae}

Cannulae (26 gauge) aimed at the AcbC (AP: $1.6 \mathrm{~mm}$ relative to bregma, ML: $\pm 2.0 \mathrm{~mm}$, and DV: $-5.9 \mathrm{~mm}$ from skull)

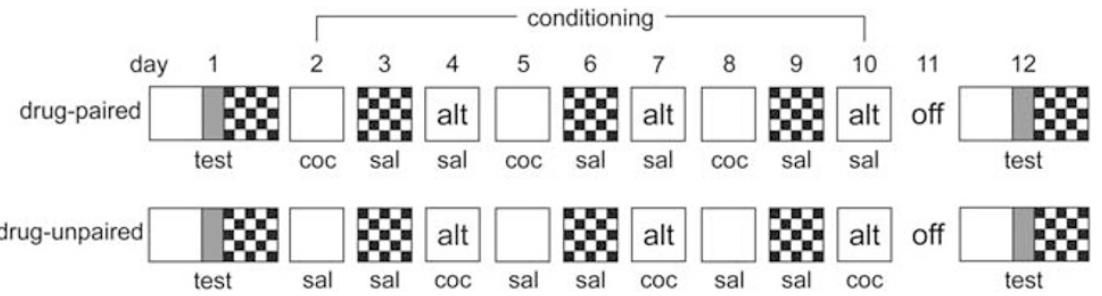

Figure I Schematic representation of the conditioned place preference procedure. On day I, both groups were tested for initial preference. Days 2-10 were conditioning days during which animals were given an injection of either cocaine or saline and confined to either one of the large outer chambers of the CPP apparatus or an alternate environment (alt). Although only one possible organization of conditioning days is shown here for each group, the groups were counterbalanced such that there were equal numbers of animals who began conditioning on day 2 in each of the three environments (white, checkered, or alternate). At $48 \mathrm{~h}$ after the last conditioning session, all animals were again tested for preference in a manner identical to day I. 
(Paxinos and Watson, 2005) were implanted as described previously (Miller and Marshall, 2005b).

\section{Tissue Preparation for Immunocytochemistry and in situ Hybridization}

At 15 min after the final CPP test or confinement session, animals were deeply anesthetized with sodium pentobarbital $(250 \mathrm{mg} / \mathrm{kg}$, i.p.) and transcardially perfused with sterile ice-cold $0.1 \mathrm{M}$ phosphate-buffered saline (PBS), $\mathrm{pH} 7.4$, followed by sterile ice-cold $4 \%$ paraformaldehyde in PBS, $\mathrm{pH}$ 7.4, with $0.1 \mathrm{mM} \mathrm{NaF}$. The time between initiation of anesthesia and perfusion was held to less than $5 \mathrm{~min}$ (Takamura et al, 2008). After removal of the brains, postfixation, and dehydration in 30\% sucrose, a total of 20 coronal sections $(40 \mu \mathrm{m}$ each for immunocytochemistry or $30 \mu \mathrm{m}$ each for in situ) were collected at the level of the nucleus Acb (beginning rostrally at $+2.3 \mathrm{~mm}$ relative to bregma) using a freezing microtome.

\section{FG-pERK Double Immunocytochemistry}

Serial sections were labeled for pERK and then FG immunoreactivity. pERK immunocytochemistry was performed as described previously (Miller and Marshall, 2005b) except that labeling was visualized using diaminobenzidine tetrahydrochloride with no metal enhancement (brown reaction product; Vector). FG labeling was then performed using procedures similar to those described for pERK with the following exceptions. All solutions were made in $0.1 \mathrm{M}$ PBS, $\mathrm{pH} 7.4$; the nonspecific and primary solutions contained $0.3 \%$ Triton X-100 (TX) and $1 \%$ normal goat serum. Tissue was incubated for $24 \mathrm{~h}$ at $4{ }^{\circ} \mathrm{C}$ in anti-FG rabbit polyclonal antibody $(1: 15,000$; Chemicon). The secondary antibody was a biotinylated goat anti-rabbit immunoglobulin G $(1: 200$; Vector). Following incubation in avidin-biotinylated peroxidase complex, the labeling was visualized with diluted Vector SG (gray reaction product).

\section{Free-floating PPE in situ Hybridization and pERK Immunocytochemistry}

PPE has been repeatedly shown to be a reliable marker for D2-expressing neurons. Investigation of the overlap of PPE and D2 mRNA in both the dorsal striatum and the nucleus Acb has shown that all detectable enkephalin neurons express D2-receptor mRNA (Le Moine et al, 1990). Freefloating tissue sections were processed through in situ hybridization as described previously (Schuller and Marshall, 2000) using a PPE mRNA antisense riboprobe (970 bp) transcribed from a cDNA in the presence of digoxigenin (DIG)-labeled UTP. Labeled sections were then incubated with an AP-conjugated anti-DIG polyclonal antibody (1:500; Roche) and chromogenically visualized using the AP substrate BCIP/NBT (Vector). pERK labeling was then performed as described above.

\section{Eticlopride-induced pERK in AcbC}

To determine the feasibility of demonstrating colocalization of PPE mRNA and pERK-ir, the following control experiment was performed. Animals $(n=4)$ were given an injection of the selective D2-antagonist eticlopride- $\mathrm{HCl}$ $(1 \mathrm{mg} / \mathrm{kg}$, i.p.; Sigma) and were killed $30 \mathrm{~min}$ after injection. Recent work by Bertran-Gonzalez et al (2008) demonstrated that administration of the D2-receptor antagonist haloperidol resulted in ERK activation only in neurons expressing the D2 receptor. Considering the extensive overlap of striatal D2 and PPE mRNAs (Curran and Watson, 1995) eticlopride should increase pERK selectively in PPE + neurons.

\section{Design and Confirmation of D1 Riboprobe}

Brain mRNA was isolated from a male Sprague-Dawley rat ( $250 \mathrm{~g}$ body weight), and the first-strand cDNA was synthesized by reverse transcription using the SuperScript First-Strand Synthesis System for RT-PCR (Invitrogen, Carlsbad, CA). Complementary DNA fragments corresponding to regions of the rat D1 receptor cDNA (11261769 of the GenBank accession number M35077) were cloned into plasmid pCRII-TOPO (Invitrogen). Using this plasmid as a template, sense and antisense single-strand RNA riboprobes were synthesized with a DIG labeling kit (Roche Diagnostics, Basel, Switzerland). When the D1 riboprobe was sequenced to confirm the accuracy of its synthesis, it displayed a $99 \%$ match to the rat D1 receptor.

\section{Free-floating D1 in situ Hybridization and pERK Immunocytochemistry}

Free-floating tissue sections were processed through in situ hybridization using a D1 mRNA antisense riboprobe (643 bp) transcribed from a cDNA in the presence of DIGUTP with a T7-RNA polymerase promoter. The antisense fragments are contained in a plasmid source (cDNAs created with the assistance of Dr Katumi Sumikawa, UC, Irvine). Tissue sections were extensively rinsed before hybridization. Riboprobe was diluted to a concentration of $1: 1000$ in hybridization buffer and applied to the tissue, which was placed in a humid chamber at $55^{\circ} \mathrm{C}$ for $16-24 \mathrm{~h}$. After hybridization, sections underwent stringent rinses and the tissue was incubated for $24 \mathrm{~h}$ at $4{ }^{\circ} \mathrm{C}$ with an $\mathrm{AP}$ conjugated sheep anti-DIG polyclonal antibody $(1: 500$; Roche) in buffer. When the intensity of the blue reaction product was sufficient to distinguish AcbC neurons under a light microscope $(16-20 \mathrm{~h})$ the sections were placed in a stop buffer (0.1 M glycine-HCl, pH 2.2) for $30 \mathrm{~min}$. pERK labeling was then performed as described above.

\section{Immunoreactivity Quantification}

Distributions of immunoreactive cells were studied by viewing the tissue with a Leica DM4000B microscope at a total magnification of either $\times 160$ or $\times 400$. All cells immunoreactive for pERK and/or FG in the AcbC were counted by the experimenter (approximate area of $2 \mathrm{~mm}^{2}$ at $1.6 \mathrm{~mm} \pm 0.5 \mathrm{~mm}$ relative to Bregma; Paxinos and Watson, 2005). This region of the AcbC has been previously shown to exhibit increased pERK in response to exposure to cocaine-paired cues (Miller and Marshall, 2005b). Immunopositive cells were counted based on criteria of optical density, size, and shape. For FG-pERK double labeling, cells were considered double-labeled if clear FG labeling 
(gray stippling) was visible within pERK + cells (uniform brown). For both PPE-pERK and D1-pERK double labeling, cells were considered double-labeled if mRNA labeling (blue) was visible around the perimeter of the pERK + cells (uniform brown). Cells were quantified in both hemispheres of multiple sections. Counts were averaged to give the mean number of each immunoreactive cell type and then divided by the area of the corresponding region to give cell counts per square millimeter.

\section{Statistics}

The experimenter was blind to treatment groups when taking all measures. One-way ANOVAs were conducted to determine differences in place preferences between groups, and to evaluate group differences in the numbers of labeled cells in the AcbC of drug-paired and drug-unpaired animals.

\section{RESULTS}

\section{FG-pERK Double Labeling}

Following CPP conditioning, the drug-paired animals expressed a preference for the environment previously paired with cocaine (Figure 2a), as evidenced by a significantly greater difference score (ie, change in time spent in the COC-paired compartment from the initial to the final test) than the drug-unpaired animals (ANOVA, $\mathrm{F}(1,15)=19.83, p<0.001)$. Additionally, the drug-paired animals showed greater levels of pERK in the AcbC than drug-unpaired controls (ANOVA, F $(1,15)=4.86, p<0.05$; Figures $2 b, d$ and e). Confirmation of this differential pERK expression supported the decision to investigate the neuronal phenotype of the cells overexpressing pERK in response to cocaine-paired cues.

Iontophoresis of FG into either the VP or the $\mathrm{SN}$ resulted in extensive retrograde labeling of striatal neurons, which in all cases included the AcbC (Figures 3 and 4). All of the FG deposits directed toward $\mathrm{SN}$ included $\mathrm{SNc}$ as well as medial parts of SN pars reticulata, targets of the AcbC projections to ventral mesencephalon (Heimer et al, 1991). In drugpaired animals, approximately equal proportions of AcbC neurons retrogradely labeled by VP or SN FG iontophoresis were also pERK + (Figure 5).

\section{PPE-pERK Double Labeling}

Following CPP conditioning, the drug-paired animals had a significantly greater difference score than the drugunpaired animals (ANOVA, F $(1,22)=7.54, p<0.05$ ) demonstrating that the drug-paired group developed a preference for the environment previously paired with cocaine (Figure 6a). AcbC cells exhibiting pERK on exposure to cocaine-paired cues failed to express PPE mRNA (Figures $6 \mathrm{~b}$ and $\mathrm{c}$ ). The absence of pERK and PPE mRNA overlap in animals expressing cocaine-CPP did not reflect an inability to colocalize these two markers, as animals treated acutely with the D2-class antagonist eticlopride ( $1 \mathrm{mg} / \mathrm{kg}$, i.p.) $30 \mathrm{~min}$ before killing showed clear colocalization of pERK and PPE mRNA in AcbC cells (Figure 6d).

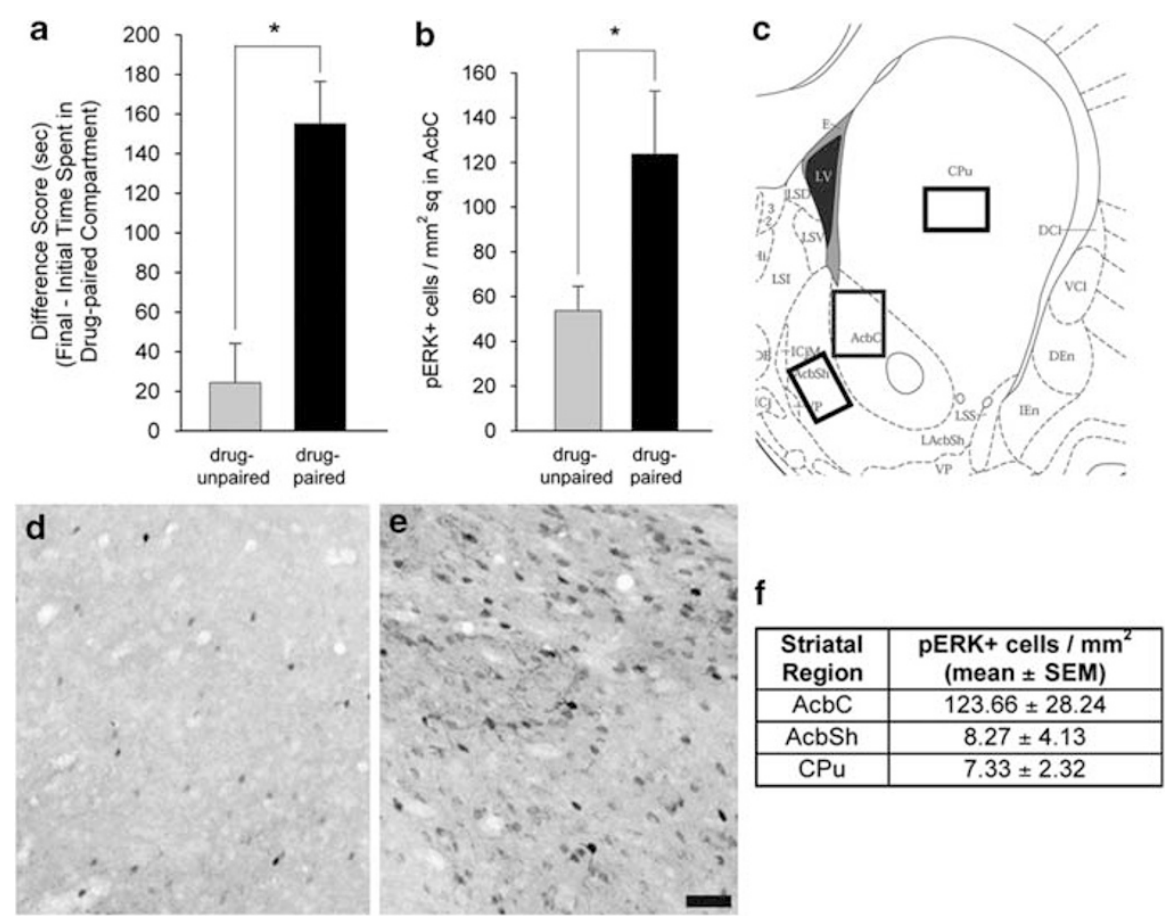

Figure 2 Conditioned place preference results and analysis of AcbC pERK immunoreactivity in animals expressing CPP. (a) COC-CPP expression in drugunpaired $(n=8)$ and drug-paired $(n=9)$ animals, indicated as change in time spent in the COC-paired compartment from the initial to the final test (difference score). * One-way ANOVA, $p<0.00 \mathrm{I}$. (b) Quantification of AcbC cells labeled for $p E R K$ immunoreactivity. * One-way ANOVA, $p<0.05$. (c) Diagram of a coronal section indicating the area of the AcbC, AcbSh, and CPu analyzed for pERK expression. (d and e) AcbC pERK immunoreactivity in drug-unpaired (d) and drug-paired (e) animals. Scale bar $=100 \mu \mathrm{m}$ for panels (d) and (e). (f) Table indicating the average number of pERK + cells in each striatal subregion. 


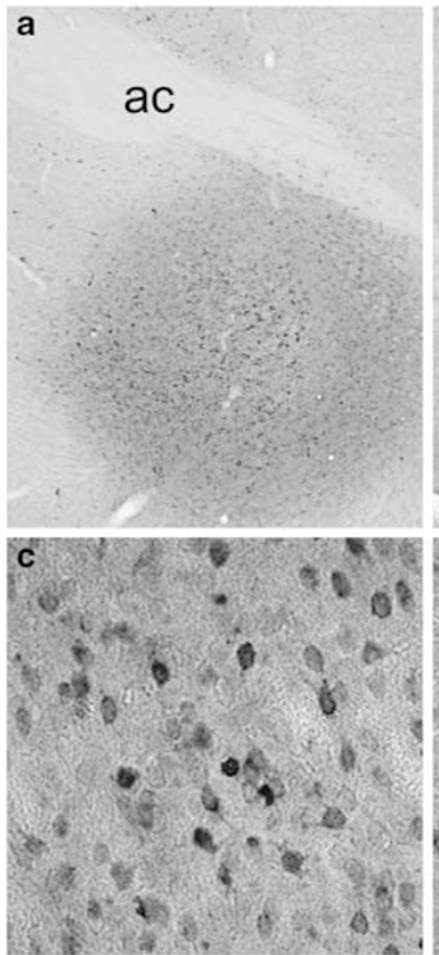

\section{$\mathrm{ml}$}

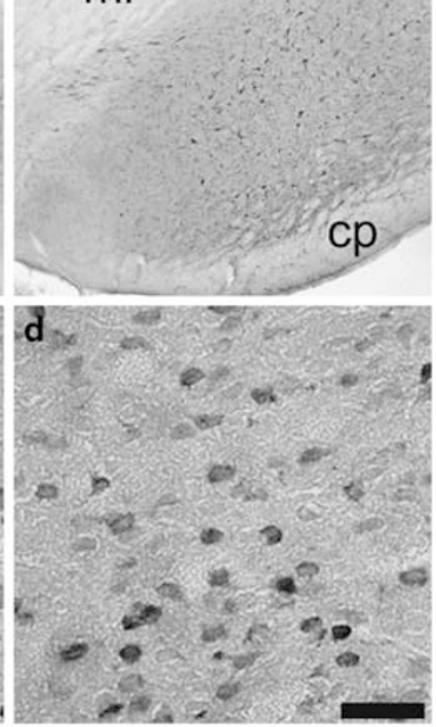

e

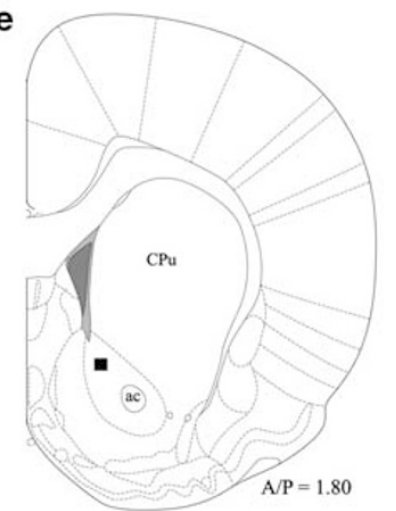

f

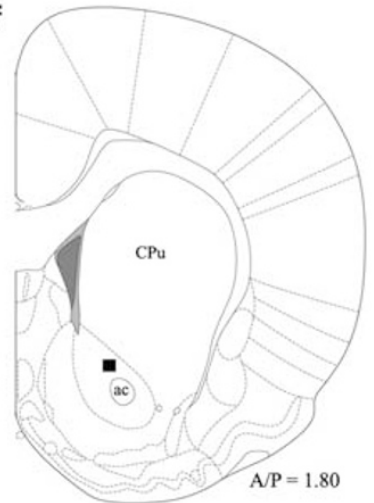

Figure 3 Results of retrograde labeling with Fluorogold. (a and b) Representative Fluorogold desposit sites in the ventral pallidum (a) and substantia nigra (b) identified by darkening of neuropil and some intensely labeled neurons; landmark abbreviations: anterior commisure (ac), medial lemniscus ( $\mathrm{ml}$ ), cerebral peduncle (cp). (c and d) AcbC FG-immunoreactivity resulting from representative FG deposits into the ventral pallidum (c) or substantia nigra (d). On average, FG deposits into the VP resulted in $220 \mathrm{FG}+$ cells/ $\mathrm{mm}^{2}$, in the AcbC, whereas SN deposits resulted in 125 cells $/ \mathrm{mm}^{2}$. Scale bar $=100 \mu \mathrm{m}$; bar in panel (d) also applies to panel c. (e and f) Schematic representations indicating where the photomicrographs in panels (c) and (d), respectively were taken.

\section{D1-pERK Double Labeling}

We developed a D1-antisense riboprobe that exhibits strong striatal cellular localization (Figures $7 \mathrm{a}$ and $\mathrm{b}$ ) and 99\% homology to the rat D1 receptor. Following CPP conditioning, the drug-paired animals had a significantly greater difference score than the drug-unpaired animals (ANOVA, $\mathrm{F}(1,16)=15.81, p<0.01)$ demonstrating that the drug-paired group developed a preference for the environment previously paired with cocaine (Figure 7c). Approximately $95 \%$ of the AcbC cells expressing pERK in

response to cocaine-paired cues contained D1 mRNA (Figures $7 \mathrm{~d}$ and e).

\section{Intra-AcbC SCH23390 Infusion and pERK Expression}

An additional experiment was conducted to test the hypothesis that agonist occupation of AcbC D1 receptors is necessary for the contextual cue-induced phosphorylation of ERK within cells of that nucleus. Rats were trained on cocaine $\mathrm{CPP}$ as in experiments described previously. On the test day, and following intra-AcbC infusion of either the D1-class antagonist SCH23390 $(0.5 \mu \mathrm{g}$ in $0.5 \mu \mathrm{l}$ saline $)$ or its vehicle, animals were confined for $15 \mathrm{~min}$ to the compartment of the CPP apparatus that had previously been paired with cocaine administration and then killed for pERK immunocytochemistry. Confinement to the cocainepaired compartment was employed instead of a standard preference test because it was regarded essential to equate the duration of exposure to the cocaine-associated context between the SCH23390- and vehicle-infused groups. This SCH23390 infusion significantly reduced the number of pERK immunoreactive cells in the AcbC relative to vehicle-infused controls (ANOVA, $\mathrm{F}(1,12)=6.20, p<0.05$; Figure 8).

\section{DISCUSSION}

Learning about the relationship between contexts and drugs of abuse depends on a network of limbic structures that includes the basolateral amygdalar complex (Hiroi and White, 1991; Whitelaw et al, 1996; Fuchs et al, 2002), the prelimbic region of the medial prefrontal cortex (Isaac et al, 1989; Tzschentke and Schmidt, 1999; Ciccocioppo et al, 2001), and the AcbC (Carelli and Ijames, 2001; Miller and Marshall, 2005a). The formation and maintenance of these associations depend on intracellular molecular signaling cascades, including activation of the MAP kinase pathway of the AcbC. Cocaine and amphetamine strongly induce pERK in the AcbC in a D1-dependent manner (Valjent et al, 2005; Bertran-Gonzalez et al, 2008), and administration of drugs that inhibit the ERK kinase MEK (mitogen activated protein kinase) blocks the establishment of a CPP for cocaine or amphetamine (Valjent et al, 2000; Gerdjikov et al, 2004). The ERK signaling cascade can be activated both by psychostimulant drugs and by drug-paired cues. Miller and Marshall (2005b) demonstrated that contextual cues previously associated with cocaine elicit phosphorylation of ERK in the AcbC and that intra-AcbC infusion of the MEK inhibitor U0126 attenuates this phosphorylation. Furthermore, this activation of ERK appears necessary not only for the execution of the behavior but also for retention of the association. In the CPP paradigm, intra-AcbC U0126 infusion immediately after retrieval impaired memory for the preference during a subsequent test (Miller and Marshall, 2005b) and results were consistent with reconsolidation interference. The likelihood that ERK activation is needed to form and/or retain associations between cues and drugs of abuse is suggested by research in other areas of learning and memory. ERK has been implicated in aspects of synaptic plasticity (eg, hippocampal long-term potentiation; English and Sweatt, 1996, 1997) and learning 

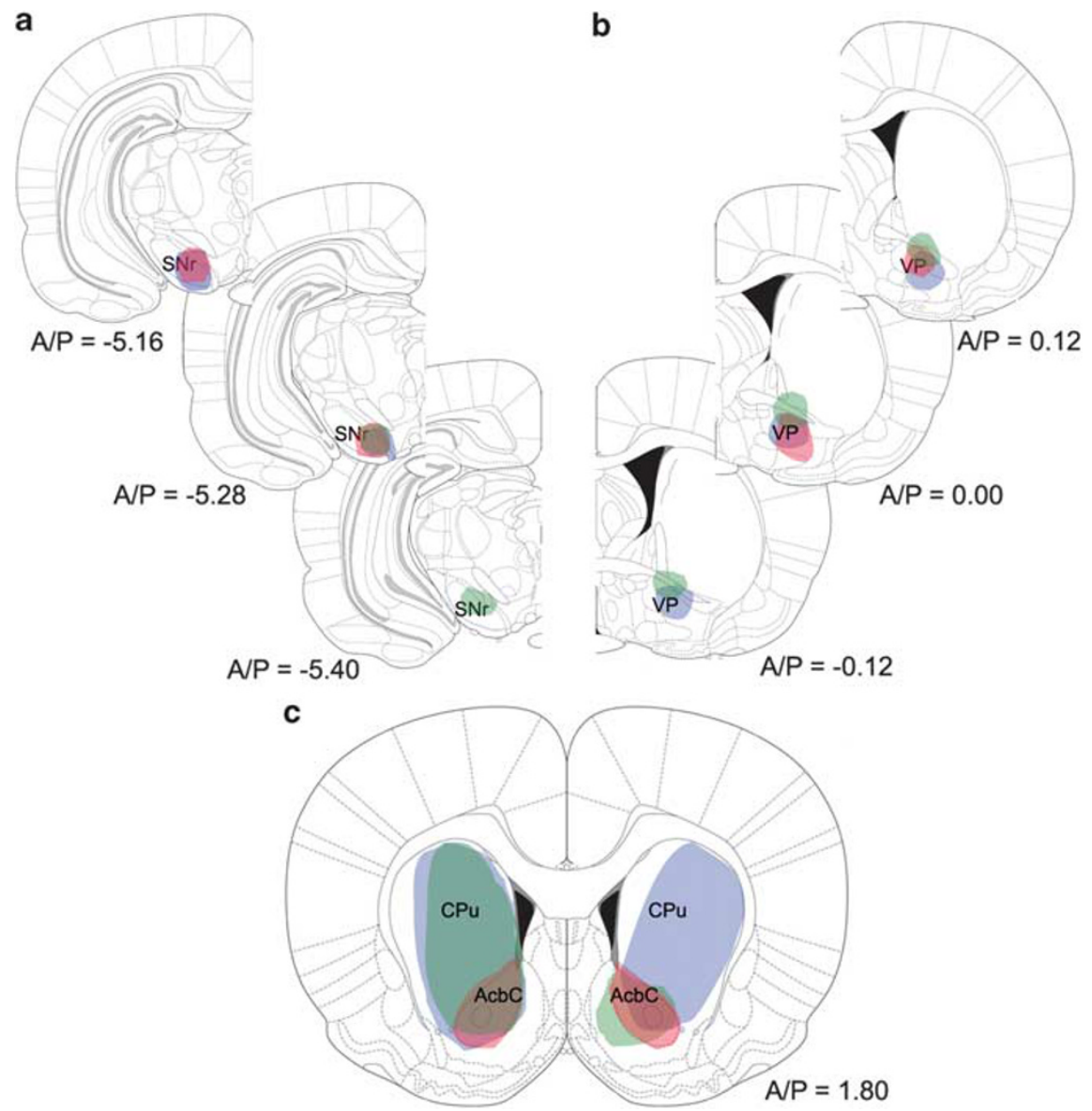

Figure 4 ( $a$ and $b$ ) Schematic representation of the anterior-posterior spread of the FG deposit sites in the substantia nigra (a) and ventral pallidum (b). Each of the three colors (red, green, and blue) represents an individual deposit. (c) Schematic representation of the striatal cell labeling produced by the FG injections diagrammed in panels (a) and (b). The color scheme in panel (c) corresponds to that in panels (a) and (b) (ie the 'blue' deposits in a, b, result in the 'blue' labeling in c). Images adapted from Paxinos and Watson (2005).
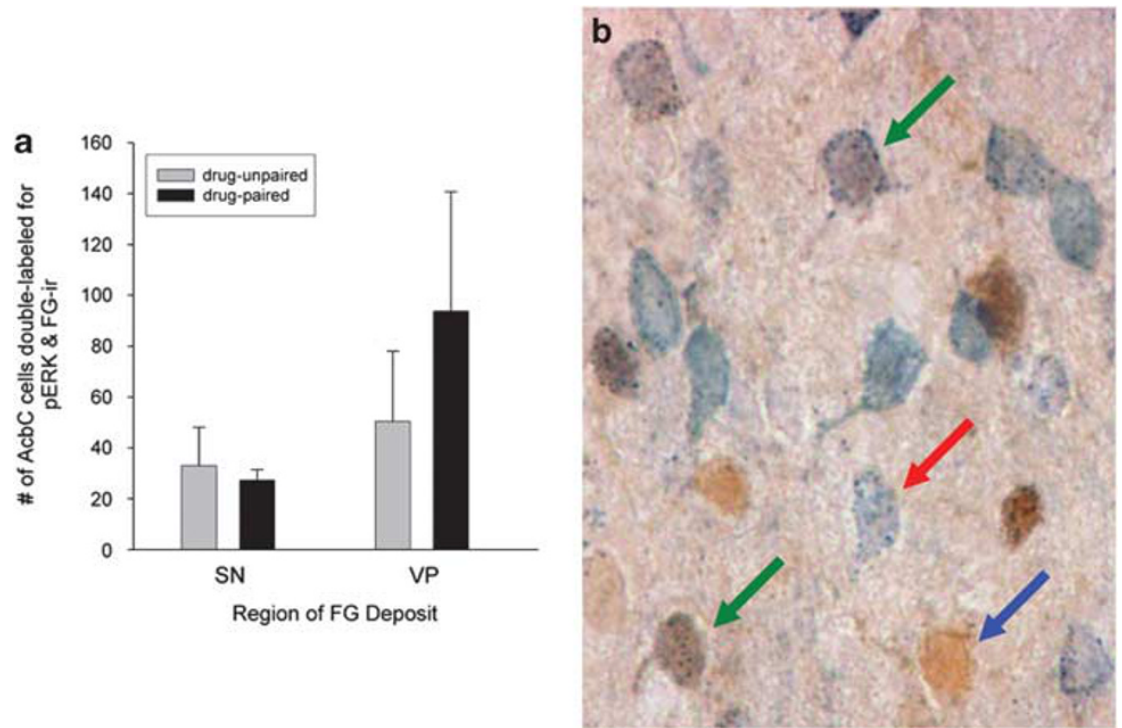

Figure 5 Analysis of FG-pERK double labeling. (a) Quantification of AcbC cells double-labeled for pERK- and FG-immunoreactivity ( $n=3$ per region of deposit). (b) Examples of AcbC pERK (blue arrow), FG (red arrow), and pERK and FG (green arrows) immunoreactivity resulting from FG iontophoresis into the VP. Double labeling was evidenced by the presence of gray stippling (FG immunoreactivity) within cells that were uniformly brown ( $\mathrm{pERK}+$ ). Scale bar $=100 \mu \mathrm{m}$. 
a

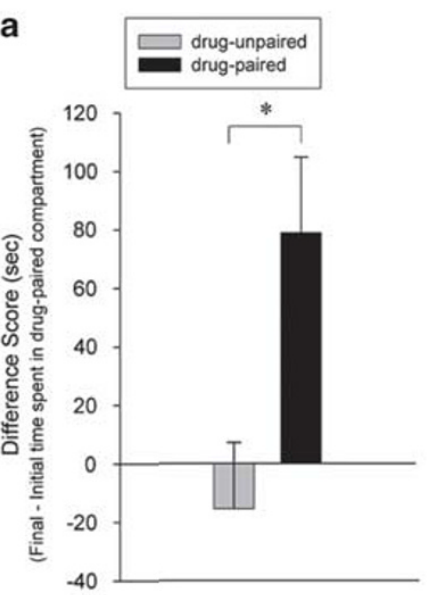

b

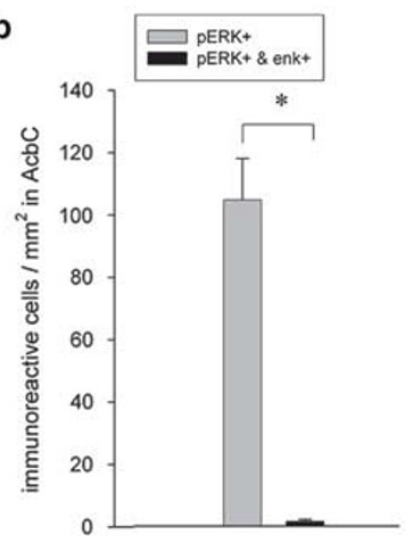

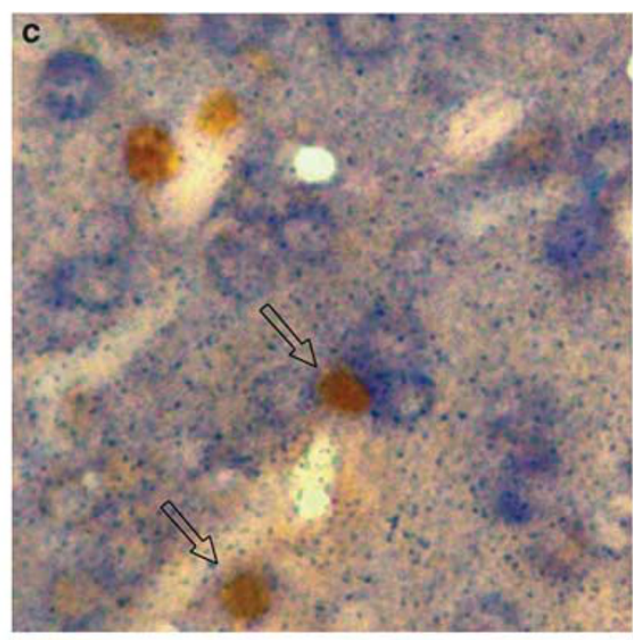

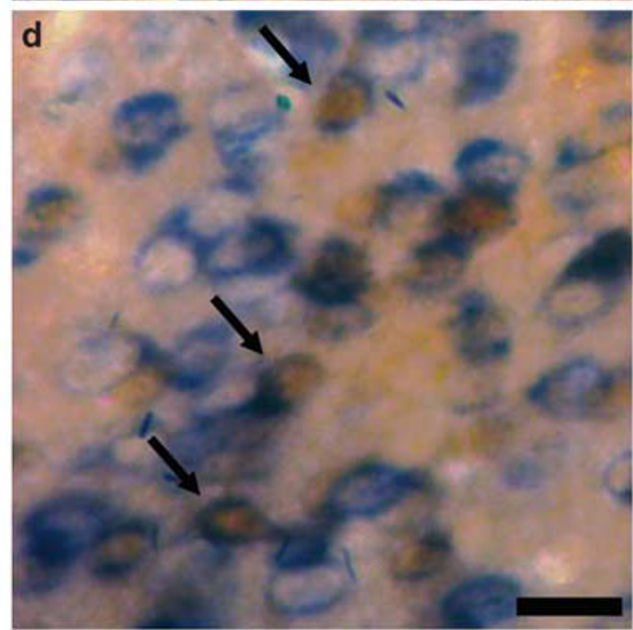

Figure 6 Analysis of AcbC pERK immunoreactivity and PPE mRNA in animals expressing CPP. (a) COC-CPP expression in drug-unpaired ( $n=12)$ and drug-paired $(n=12)$ animals, indicated as change in time spent in the COC-paired compartment from the initial to the final test (difference score). * Oneway ANOVA, $p<0.05$. (b) Quantification of AcbC pERK + cells and cells double-labeled for pERK and PPE in drug-paired animals. (c and d) Examples of AcbC cells double-labeled for pERK and PPE mRNA (solid arrows) or single labeled for pERK immunoreactivity (open arrows) in COC-paired (c) and eticlopride-treated control (d) animals. Double-labeled cells were evidenced by blue (PPE mRNA) labeling visible around the perimeter of cells that were uniformly brown $(p E R K+)$. Scale bar $=100 \mu \mathrm{m}$; bar in panel (d) also applies to panel (c).

(eg, long-term memory storage for fear conditioning, spatial learning, sensitization, and object recognition; Atkins et al, 1998; Selcher et al, 1999; Kelly et al, 2003; Sharma et al, 2003). Despite the recognized role of ERK in expression and retention of psychostimulant-cue memories, little work has been done to identify the specific neuron population(s) in which ERK is activated during such memories. The present experiments were conducted as a critical first step in understanding cocaine cue-elicited ERK-dependent neuronal plasticity. The results presented here point consistently to the conclusion that the D1-expressing cells of the AcbC are the neurons in which contextual cues activate ERK. Furthermore, the D1 receptors located on these neurons appear necessary for the cue-induced expression of pERK.

The results of the retrograde-labeling study showed that approximately equal proportions of AcbC neurons labeled by VP or SN FG iontophoresis were also pERK +. The dorsal striatum and nucleus Acb share many organizational features. In both regions, the modulatory effect of dopaminergic afferents is thought to be mediated primarily by the activation of D1- and D2-class DA receptors (Le Moal and Simon, 1991) that are principally expressed in separate neurons (Le Moine and Bloch, 1995). Also, dorsal striatal and Acb cells expressing D1 receptors co-express substance $\mathrm{P}$, whereas cells expressing D2 receptors co-express enkephalin (Curran and Watson, 1995). However, the dorsal striatum and Acb differ in the terminal sites for these neurochemically distinct subpopulations of neurons. Whereas the D1/substance P-expressing cells of dorsal striatum project primarily to the $\mathrm{SN}$ pars reticulata, and the D2/enkephalin expressing cells project to the external segment of the globus pallidus (Gerfen et al, 1990 ), this projection selectivity is not entirely preserved in the Acb. D1 receptors are contained in both the Acb-nigral and Acb-pallidal projections, whereas D2 receptors are selectively expressed in the Acb-pallidal projection (Robertson and Jian, 1995; Lu et al, 1998). Because the retrograde-labeling study resulted in FG-pERK colocalization in both the Acb-nigral and Acb-pallidal projections, it can be concluded that the cue-induced pERK is not occurring solely in the AcbC D2 cell population. This result leaves open the possibility that cue-induced pERK could be occurring in both populations of AcbC medium spiny neurons or solely in the D1-containing cells. 

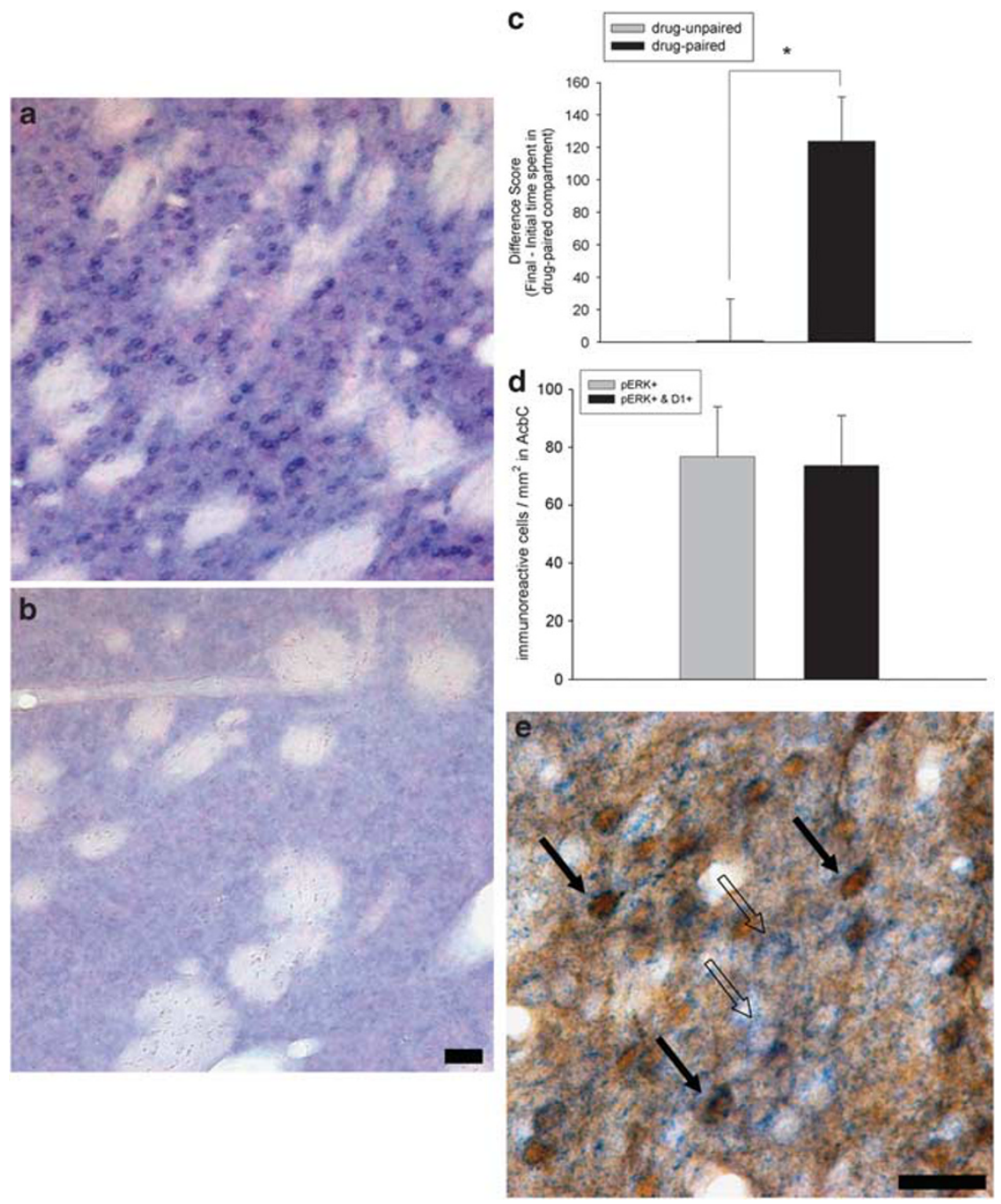

Figure 7 Analysis of AcbC pERK immunoreactivity and DI mRNA in animals expressing CPP. (a and b) Photomicrographs of striatal tissue sections labeled with DI antisense (a) or sense (b) riboprobe. (c) COC-CPP expression in drug-unpaired $(n=6)$ and drug-paired ( $n=12)$ animals, indicated as change in time spent in the COC-paired compartment from the initial to the final test (difference score). * One-way ANOVA, $p<0.005$. (d) Quantification of AcbC pERK + cells and cells double-labeled for pERK and DI in drug-paired animals. (e) Examples of AcbC cells double-labeled for pERK and DI mRNA in COC-paired animals (solid arrows), as in contrast with cells single-labeled for DI mRNA (open arrows). The criteria for identifying cells as DI/pERK double labeled were the same as indicated for the PPE/pERK cells (Figure 6 legend). Scale bars $=100 \mu$ m; bar in panel (b) also applies to panel (a).

Investigations of the gene expression characteristics of the AcbC cell population combined in situ hybridization for mRNAs of the neuropeptide precursor PPE, or the D1 receptor, with immunocytochemistry for pERK. These experiments revealed that contextual cues associated with cocaine contexts did not induce pERK in the PPEexpressing neurons of the AcbC. The absence of significant colocalization of cue-induced pERK with PPE cannot be ascribed to a failure of the PPE + neurons to display pERK activation, or our inability to detect colocalized pERK and PPE mRNA, because administration of the D2-class antagonist eticlopride to animals before killing resulted in significant numbers of PPE + neurons containing pERK. Considering the extensive overlap of striatal D2 and PPE mRNAs (Curran and Watson, 1995), this finding fits with recent work demonstrating that administration of haloperidol results in ERK activation only in neurons expressing the D2 receptor (Bertran-Gonzalez et al, 2008). Our additional experiment, combining in situ hybridization of D1 mRNA with pERK, showed directly that the
D1-expressing cells of the AcbC are those in which contextual cues activate ERK after training.

These findings support the role of AcbC D1 neurons in plasticity related to drug seeking, but leaved unresolved the possible role of striatal D2/PPE-expressing neurons in these associations. The D2/PPE neurons appear to be activated during exposure to psychostimulant drugs in novel contexts. Specifically, psychostimulant drugs induce immediate early genes (IEGs) principally in D1 receptorcontaining striatal and accumbens neurons (Berretta et al, 1992; Cenci et al, 1992; Berretta et al, 1993; Johansson et al, 1994; Ruskin and Marshall, 1994), but when given in a novel environment they also induce $c$-fos expression in D2 receptor-containing neurons (Badiani et al, 1999; Hope et al, 2006; Uslaner et al, 2001). Activation of the D2-striatal neuron population by psychostimulant drugs administered in a novel environment appears to involve corticostriatal pathway activation because (i) transection of corticostriatal fibers selectively blocks amphetamine-evoked c-fos expression in striatal D2 neurons (Ferguson and Robinson, 2004) 

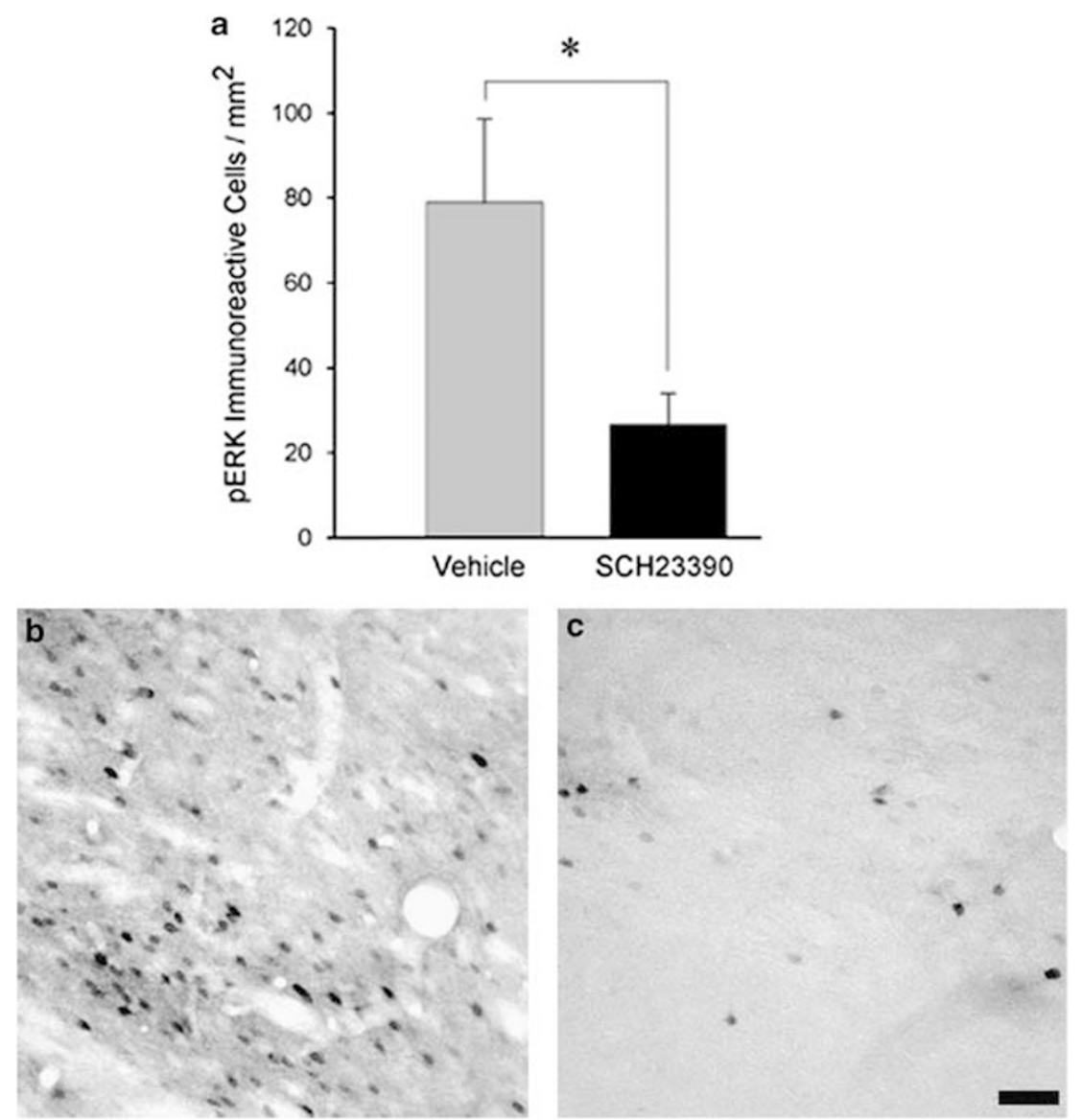

Figure 8 Effect of intra-AcbC infusion of the DI-class antagonist SCH23390 ( $0.5 \mu \mathrm{g}$ in $0.5 \mu \mathrm{l}$ saline) on cue-induced pERK immunoreactivity. (a) SCH23390 significantly antagonizes the expression of AcbC pERK in animals exposed to cocaine-paired cues ( $n=7$ per treatment group). $*$ One-way ANOVA, $p<0.05$. ( $b$ and c) AcbC pERK immunoreactivity in animals receiving intra-AcbC infusions of either vehicle (b) or SCH23390 (c). Scale bar $=100 \mu \mathrm{m}$; bar in panel (c) also applies to panel (b).

and (ii) activation of the neocortex without psychostimulant administration induces IEGs preferentially in striatal D2 neurons (Berretta et al, 1997; Parthasarathy and Graybiel, 1997). Considered together with the present findings, these results lead to the hypothesis that the D1 and D2 cell populations have differing roles in learning about drugcontext associations. Activation of the striatal D2 cell population during CPP training may signal the coincidence of then-novel contexts with psychostimulant drugs, whereas plasticity of the ERK signaling pathway within the D1+ cells may occur following repeated pairing of the context with the psychostimulant drug.

The data presented in this manuscript contribute novel information regarding the ability of cues to increase ERK activation in the AcbC by a D1 receptor-dependent mechanism. The present results, employing intra-AcbC infusions of SCH23390 during exposure of rats to the context previously paired with cocaine, strongly suggest a necessary role for the DA D1 receptors in cue-induced pERK expression within D1 cells. This interpretation is supported by previous work showing, by voltammetry and microdialysis, an increase in DA signal in the AcbC of animals exposed to drug-paired cues. Using fast-scan cyclic voltammetry to measure subsecond changes in dopamine in the nucleus Acb of rats performing self-administration, Phillips et al (2003) demonstrated that an audio- visual stimulus previously paired with cocaine infusion evoked nucleus accumbens DA release that was similar in amplitude to that elicited directly by cocaine infusion. Importantly, the audiovisual stimulus did not evoke DA release in rats that had never experienced the stimulus paired with cocaine delivery, suggesting that the DA signal required a learned association between cocaine and the stimulus previously paired with its infusion. Using microdialysis in a similar self-administration experiment, Weiss et al (2000) demonstrated that presentation of a stimulus previously paired with cocaine infusion results in increased DA efflux in the AcbC The data presented here suggest that the DA released in the AcbC by cocaine-paired contexts must interact with D1 receptors in order to activate pERK in those cells.

Not only are D1 receptors necessary for the pERK expression induced by a cocaine-paired context but also other studies have suggested that they are needed for the expression of preference for that drug-paired context. Systemic or intra-AcbC administration of the D1 antagonist SCH23390 has been shown to block expression of psychostimulant CPP (Hiroi and White, 1991; Mizoguchi et al, 2004; Tan, 2008). However, work from Cervo and Samanin (1995) failed to replicate this effect and instead showed enhanced expression of cocaine CPP following systemic administration of SCH23390. Although a role for D1 receptors in 
cue-induced activation of ERK appears certain, further research is required to explore the conditions under which this AcbC D1 receptor occupation is needed for guiding cue-induced drug-seeking behavior.

In summary, the data presented in this manuscript provide strong evidence for a role for AcbC DA D1 receptors in the neuronal responses to cocaine-associated stimuli. We have demonstrated that the activation of ERK accompanying retrieval of drug-cue memories occurs specifically in the D1 cell population of the AcbC and that D1 receptors are necessary for that ERK phosphorylation. By delineating which cell population expresses ERKdependent plasticity, we have provided information that could allow for the development of molecular approaches to target the neurons displaying pERK over-expression related to addiction.

\section{ACKNOWLEDGEMENTS}

We acknowledge Dr Katumi Sumikawa and Eddie Ibrahim for their technical assistance and Dr Steve O'Dell for his helpful comments regarding this manuscript. This research was supported by PHS grant DA 021807 to JFM.

\section{DISCLOSURE}

The authors declare no conflict of interest.

\section{REFERENCES}

Atkins CM, Selcher JC, Petraitis JJ, Trzaskos JM, Sweatt JD (1998). The MAPK cascade is required for mammalian associative learning. Nat Neurosci 1: 602-609.

Badiani A, Oates MM, Day HE, Watson SJ, Akil H, Robinson TE (1999). Environmental modulation of amphetamine-induced cfos expression in D1 versus D2 striatal neurons. Behav Brain Res 103: 203-209.

Beckstead RM, Domesick VB, Nauta WJ (1979). Efferent connections of the substantia nigra and ventral tegmental area in the rat. Brain Res 175: 191-217.

Berhow MT, Hiroi N, Nestler EJ (1996). Regulation of ERK (extracellular signal regulated kinase), part of the neurotrophin signal transduction cascade, in the rat mesolimbic dopamine system by chronic exposure to morphine or cocaine. J Neurosci 16: 4707-4715.

Berretta S, Parthasarathy HB, Graybiel AM (1997). Local release of GABAergic inhibition in the motor cortex induces immediateearly gene expression in indirect pathway neurons of the striatum. J Neurosci 17: 4752-4763.

Berretta S, Robertson HA, Graybiel AM (1992). Dopamine and glutamate agonists stimulate neuron-specific expression of Foslike protein in the striatum. J Neurophysiol 68: 767-777.

Berretta S, Robertson HA, Graybiel AM (1993). Neurochemically specialized projection neurons of the striatum respond differentially to psychomotor stimulants. Prog Brain Res 99: 201-205.

Bertran-Gonzalez J, Bosch C, Maroteaux M, Matamales M, Herve $\mathrm{D}$, Valjent $\mathrm{E}$ et al. (2008). Opposing patterns of signaling activation in dopamine D1 and D2 receptor-expressing striatal neurons in response to cocaine and haloperidol. J Neurosci 28: 5671-5685.

Bolam JP, Wainer BH, Smith AD (1984). Characterization of cholinergic neurons in the rat neostriatum. A combination of choline acetyltransferase immunocytochemistry, Golgi-impregnation and electron microscopy. Neuroscience 12: 711-718.
Carelli RM, Ijames SG (2001). Selective activation of accumbens neurons by cocaine-associated stimuli during a water/cocaine multiple schedule. Brain Res 907: 156-161.

Cenci MA, Campbell K, Wictorin K, Bjorklund A (1992). Striatal cfos induction by cocaine or apomorphine occurs preferentially in output neurons projecting to the substantia nigra in the Rat. Eur J Neurosci 4: 376-380.

Cervo L, Samanin R (1995). Effects of dopaminergic and glutamatergic receptor antagonists on the acquisition and expression of cocaine conditioning place preference. Brain Res 673: 242-250.

Chang HT, Kitai ST (1985). Projection neurons of the nucleus accumbens: an intracellular labeling study. Brain $\operatorname{Re} s$ 347: $112-116$.

Chao J, Nestler EJ (2004). Molecular neurobiology of drug addiction. Annu Rev Med 55: 113-132.

Childress A, Ehrman R, McLellan AT, O'Brien C (1988). Conditioned craving and arousal in cocaine addiction: a preliminary report. NIDA Res Monogr 81: 74-80.

Ciccocioppo R, Sanna PP, Weiss F (2001). Cocaine-predictive stimulus induces drug-seeking behavior and neural activation in limbic brain regions after multiple months of abstinence: reversal by $\mathrm{D}(1)$ antagonists. Proc Natl Acad Sci USA 98: 1976-1981.

Curran EJ, Watson Jr SJ (1995). Dopamine receptor mRNA expression patterns by opioid peptide cells in the nucleus accumbens of the rat: a double in situ hybridization study. J Comp Neurol 361: 57-76.

English JD, Sweatt JD (1996). Activation of p42 mitogen-activated protein kinase in hippocampal long term potentiation. J Biol Chem 271: 24329-24332.

English JD, Sweatt JD (1997). A requirement for the mitogenactivated protein kinase cascade in hippocampal long term potentiation. J Biol Chem 272: 19103-19106.

Ferguson SM, Robinson TE (2004). Amphetamine-evoked gene expression in striatopallidal neurons: regulation by corticostriatal afferents and the ERK/MAPK signaling cascade. J Neurochem 91: 337-348.

Fricks-Gleason AN, Marshall JF (2008). Post-retrieval \{beta\}adrenergic receptor blockade: effects on extinction and reconsolidation of cocaine-cue memories. Learn Mem 15: 643-648.

Fuchs RA, Weber SM, Rice HJ, Neisewander JL (2002). Effects of excitotoxic lesions of the basolateral amygdala on cocaineseeking behavior and cocaine conditioned place preference in rats. Brain Res 929: 15-25.

Gerdjikov TV, Ross GM, Beninger RJ (2004). Place preference induced by nucleus accumbens amphetamine is impaired by antagonists of ERK or p38 MAP kinases in rats. Behav Neurosci 118: $740-750$.

Gerfen CR, Engber TM, Mahan LC, Susel Z, Chase TN, Monsma Jr FJ et al. (1990). D1 and D2 dopamine receptor-regulated gene expression of striatonigral and striatopallidal neurons. Science 250: $1429-1432$.

Groenewegen HJ, Wright CI, Beijer AV, Voorn P (1999). Convergence and segregation of ventral striatal inputs and outputs. Ann N Y Acad Sci 877: 49-63.

Heimer L, Zahm DS, Churchill L, Kalivas PW, Wohltmann C (1991). Specificity in the projection patterns of accumbal core and shell in the rat. Neuroscience 41: 89-125.

Hiroi N, White NM (1991). The lateral nucleus of the amygdala mediates expression of the amphetamine-produced conditioned place preference. J Neurosci 11: 2107-2116.

Hope BT, Simmons DE, Mitchell TB, Kreuter JD, Mattson BJ (2006). Cocaine-induced locomotor activity and Fos expression in nucleus accumbens are sensitized for 6 months after repeated cocaine administration outside the home cage. Eur J Neurosci 24: $867-875$. 
Hyman SE, Malenka RC, Nestler EJ (2006). Neural mechanisms of addiction: the role of reward-related learning and memory. Annu Rev Neurosci 29: 565-598.

Institute of Animal Resources, Commission on Life Sciences, National Research Council (1996). Guide for the Care and Use of Laboratory Animals. Washington, DC: National Academy Press.

Isaac WL, Nonneman AJ, Neisewander J, Landers T, Bardo MT (1989). Prefrontal cortex lesions differentially disrupt cocainereinforced conditioned place preference but not conditioned taste aversion. Behav Neurosci 103: 345-355.

Johansson B, Lindstrom K, Fredholm BB (1994). Differences in the regional and cellular localization of $\mathrm{c}$-fos messenger RNA induced by amphetamine, cocaine and caffeine in the rat. Neuroscience 59: 837-849.

Kalivas PW (2004). Recent understanding in the mechanisms of addiction. Curr Psychiatry Rep 6: 347-351.

Kelly A, Laroche S, Davis S (2003). Activation of mitogen-activated protein kinase/extracellular signal-regulated kinase in hippocampal circuitry is required for consolidation and reconsolidation of recognition memory. J Neurosci 23: 5354-5360.

Kemp JM, Powell TP (1971). The structure of the caudate nucleus of the cat: light and electron microscopy. Philos Trans $R$ Soc Lond B Biol Sci 262: 383-401.

Kita H (1993). GABAergic circuits of the striatum. Prog Brain Res 99: $51-72$.

Le Moal M, Simon H (1991). Mesocorticolimbic dopaminergic network: functional and regulatory roles. Physiol Rev 71: 155-234.

Le Moine C, Bloch B (1995). D1 and D2 dopamine receptor gene expression in the rat striatum: sensitive cRNA probes demonstrate prominent segregation of D1 and D2 mRNAs in distinct neuronal populations of the dorsal and ventral striatum. J Comp Neurol 355: 418-426.

Le Moine C, Normand E, Guitteny AF, Fouque B, Teoule R, Bloch B (1990). Dopamine receptor gene expression by enkephalin neurons in rat forebrain. Proc Natl Acad Sci USA 87: 230-234.

Liao RM (2008). Development of conditioned place preference induced by intra-accumbens infusion of amphetamine is attenuated by co-infusion of dopamine D1 and D2 receptor antagonists. Pharmacol Biochem Behav 89: 367-373.

Lu XY, Churchill L, Kalivas PW (1997). Expression of D1 receptor mRNA in projections from the forebrain to the ventral tegmental area. Synapse 25: 205-214.

Lu XY, Ghasemzadeh MB, Kalivas PW (1998). Expression of D1 receptor, D2 receptor, substance $\mathrm{P}$ and enkephalin messenger RNAs in the neurons projecting from the nucleus accumbens. Neuroscience 82: 767-780.

Miller CA, Marshall JF (2005a). Altered Fos expression in neural pathways underlying cue-elicited drug seeking in the rat. Eur J Neurosci 21: 1385-1393.

Miller CA, Marshall JF (2005b). Molecular substrates for retrieval and reconsolidation of cocaine-associated contextual memory. Neuron 47: 873-884.

Mizoguchi H, Yamada K, Mizuno M, Mizuno T, Nitta A, Noda Y et al. (2004). Regulations of methamphetamine reward by extracellular signal-regulated kinase 1/2/ets-like gene-1 signaling pathway via the activation of dopamine receptors. Mol Pharmacol 65: 1293-1301.

Mogenson GJ, Yang CR (1991). The contribution of basal forebrain to limbic-motor integration and the mediation of motivation to action. Adv Exp Med Biol 295: 267-290.

Parthasarathy HB, Graybiel AM (1997). Cortically driven immediate-early gene expression reflects modular influence of sensorimotor cortex on identified striatal neurons in the squirrel monkey. J Neurosci 17: 2477-2491.
Paxinos G, Watson C (2005). The Rat Brain in Stereotaxic Coordinates, Fifth Edition Elselvier Academic Press: Burlington, MA.

Phillips PE, Stuber GD, Heien ML, Wightman RM, Carelli RM (2003). Subsecond dopamine release promotes cocaine seeking. Nature 422: 614-618.

Robertson GS, Jian M (1995). D1 and D2 dopamine receptors differentially increase Fos-like immunoreactivity in accumbal projections to the ventral pallidum and midbrain. Neuroscience 64: 1019-1034.

Ruskin DN, Marshall JF (1994). Amphetamine- and cocaineinduced fos in the rat striatum depends on D2 dopamine receptor activation. Synapse 18: 233-240.

Schuller JJ, Marshall JF (2000). Acute immediate-early gene response to 6-hydroxydopamine infusions into the medial forebrain bundle. Neuroscience 96: 51-58.

Schultz W, Dayan P, Montague PR (1997). A neural substrate of prediction and reward. Science 275: 1593-1599.

Selcher JC, Atkins CM, Trzaskos JM, Paylor R, Sweatt JD (1999). A necessity for MAP kinase activation in mammalian spatial learning. Learn Mem 6: 478-490.

Sharma SK, Sherff CM, Shobe J, Bagnall MW, Sutton MA, Carew TJ (2003). Differential role of mitogen-activated protein kinase in three distinct phases of memory for sensitization in Aplysia. J Neurosci 23: 3899-3907.

Smith AD, Bolam JP (1990). The neural network of the basal ganglia as revealed by the study of synaptic connections of identified neurones. Trends Neurosci 13: 259-265.

Takamura H, Ichisaka S, Watanabe K, Toigawa M, Hata Y (2008). Effects of anesthesia on immunohistochemical detection of phosphorylated extracellular signal-regulated kinase in cerebral cortex. J Neurosci Methods 170: 300-304.

Tan SE (2008). Roles of hippocampal NMDA receptors and nucleus accumbens D1 receptors in the amphetamineproduced conditioned place preference in rats. Brain Res Bull 77: 412-419.

Tzschentke TM, Schmidt WJ (1999). Functional heterogeneity of the rat medial prefrontal cortex: effects of discrete subarea-specific lesions on drug-induced conditioned place preference and behavioural sensitization. Eur J Neurosci 11: 4099-4109.

Uslaner J, Badiani A, Day HE, Watson SJ, Akil H, Robinson TE (2001). Environmental context modulates the ability of cocaine and amphetamine to induce c-fos mRNA expression in the neocortex, caudate nucleus, and nucleus accumbens. Brain Res 920: $106-116$.

Valjent E, Corvol JC, Pages C, Besson MJ, Maldonado R, Caboche J (2000). Involvement of the extracellular signalregulated kinase cascade for cocaine-rewarding properties. J Neurosci 20: 8701-8709.

Valjent E, Pascoli V, Svenningsson P, Paul S, Enslen H, Corvol JC et al. (2005). Regulation of a protein phosphatase cascade allows convergent dopamine and glutamate signals to activate ERK in the striatum. Proc Natl Acad Sci USA 102: 491-496.

Weiss F, Maldonado-Vlaar CS, Parsons LH, Kerr TM, Smith DL, Ben-Shahar O (2000). Control of cocaine-seeking behavior by drug-associated stimuli in rats: effects on recovery of extinguished operant-responding and extracellular dopamine levels in amygdala and nucleus accumbens. Proc Natl Acad Sci USA 97: 4321-4326.

White FJ, Wang RY (1986). Electrophysiological evidence for the existence of both D-1 and D-2 dopamine receptors in the rat nucleus accumbens. J Neurosci 6: 274-280.

Whitelaw RB, Markou A, Robbins TW, Everitt BJ (1996). Excitotoxic lesions of the basolateral amygdala impair the acquisition of cocaine-seeking behaviour under a second-order schedule of reinforcement. Psychopharmacology (Berl) 127: 213-224. 